\title{
The Effect of Metadiscourse Instruction on Iranian EFL Learners' Speaking Ability
}

\author{
Touran Ahour ${ }^{1} \&$ Saeideh Entezari Maleki ${ }^{1}$ \\ ${ }^{1}$ Department of English, College of Persian Literature and Foreign Languages, Tabriz Branch, Islamic Azad \\ University, Tabriz, Iran \\ Correspondence: Touran Ahour, Department of English, College of Persian Literature and Foreign Languages, \\ Tabriz Branch, Islamic Azad University, Tabriz, Iran. Tel: 98-914-114-9079. E-mail: ahour@iaut.ac.ir, \\ torahour2@yahoo.com
}

Received: July 28, 2014 Accepted: August 29, 2014 Online Published: September 22, 2014

doi:10.5539/elt.v7n10p69 URL: http://dx.doi.org/10.5539/elt.v7n10p69

\begin{abstract}
This study attempted to unveil the effect of metadiscourse instruction on the improvement of the speaking ability of Iranian EFL learners. After the administration of a language proficiency test, 34 homogeneous participants were assigned into the experimental and control groups. Then, the two groups were compared on their speaking ability. After the homogeneity of the participants was confirmed, both groups underwent 4 sessions of instruction. The experimental group received metadiscourse instruction, while the control group received no instruction. At the end of the treatment, both groups took part in the speaking posttest. The results indicated that the speaking performance of the experimental group was significantly higher than the control group. In addition, the comparison of the pretest and posttest of the experimental group proved an improvement in their speaking ability; while the same comparison in the control group didn't suggest any improvement. Therefore, teachers can benefit from metadiscourse instruction to enhance the speaking ability of their students.
\end{abstract}

Keywords: metadiscourse instruction, speaking ability, textual metadiscourse

\section{Introduction}

Speaking is an interactive process which leads to constructing meaning that involves the development of a particular type of production, reception, and information processing in its typical grammatical, lexical, and discourse patterns (Burns \& Joyce, 1997). That is why Webb (1982) believes that oral practice is necessary for speaking. This idea is acceptable truly, but what if the time passes and people do not get the ability they wish during their instructions. Since problematic speaking can lead the speech of the learners to break down, a more careful insight to the useful ways of speech instruction is needed in English learning environment. Thus, the main purpose of the present study was to examine the effectiveness of explicit teaching of metadiscourse markers on students' speaking ability in general.

Nash (1992) defines metadiscourse as a kind of commentary, which is made in speaking or writing. He believes the essential feature of this commentary is that it is not added to the text, by a footnote or a postscript. However, it is combined with it, in the shape of words and phrases fitted into the unfolding message. Metadiscourse is the author's linguistic and rhetorical manifestation in the text in order to "bracket the discourse organization and the expressive implications of what is being said" (Schiffrin, 1980, p. 231). Hyland (1998) believes that metadiscourse is recognized as an aspect of our everyday language which forms an important means of facilitating communication, supports the writer's position, and builds a relationship with an audience. Therefore, it is a major feature of the ways we communicate in a range of genres and settings.

Camiciottoli (2003) claims in L2 instructional contexts, an awareness of metadiscourse is particularly useful in helping non-native speakers of English with the difficult task of grasping the writer's stance when reading challenging authentic materials. Bruce (1989) suggests that this ability enables non-native learners to better follow the writer's line of reasoning in argumentative texts. Kopple (1997) observes that specific instruction on metadiscourse can be useful to help L2 readers learn to distinguish factual content from the writer's commentary.

Based on Kong and Xin (2009), the uses of metadiscourse display different characteristics in various genres and styles. They believe the taxonomies of metadiscourse generally fall into two main categories of textual and 
interpersonal. They classified textual metadiscourse into seven categories of logical connectives, interpretative markers, attributors, validity markers, attitudinal markers, commentaries, and clarifying connectives. Among these categories, logical connectives are subcategorized to different parts depending on their occurrences and functions. Four of these logical subcategories (i.e, additional connectives, contrastive connectives, sequencers, and summative connectives ...) were chosen for instruction during the present research.

It should be noted that teaching metadiscourse means sensitizing students to rhetorical effects and features that exist within a given genre and community, and give them enough sources to interact with their readers in their own world (Hyland, 2005; Swales, 1990). According to Amiryousefi and Eslami Rasekh (2010), to teach metadiscourse features appropriately, teachers need to (1) understand their students' target needs; (2) consider the students' culturally prior learning experiences, which may be different from what is expected by the target readers; (3) view learning to write as learning to use language to encourage their students to see the target language as a way of meaning making and interaction with their readers, and put emphasis on the importance of the interactions by teaching them how certain devices can be exploited to construct such interactions and dialogues with the readers; (4) use authentic texts and expose their students to the most productive and frequently used metadiscourse features to make them familiar with their use and functions; (5) provide students with the tasks of manipulating and producing texts to identify metadiscourse features, and (6) provide the students with actual writing situations to actually use and test their knowledge and understandings of metadiscourse (Hyland, 2005, pp. 181-193).

In this regard, having an eye to help language teachers to get better results in their classes, the researchers attempted to suggest them an effective way to remove some metalanguage problems in their instructional phase to help a better and faster speech learning enhancement beside practice. To fulfill the purpose of the study, the following research questions were posed:

1) Is there a significant difference in the mean speaking scores of the group of EFL learners who received metadiscourse instruction and those who received no metadiscourse instruction?

2) Is there a significant difference between the post-test and the pre-test mean speaking scores of the group of EFL learners who received metadiscourse instruction?

3) Is there a significant difference between the post-test and the pre-test mean speaking scores of the group of EFL learners who received no metadiscourse instruction?

\section{Method}

\subsection{Participants}

The participants of the present study included 50 Iranian male and female university students from Islamic Azad University Tehran North Branch. They studied English language teaching for an Associate degree. Their age range was 22-35 years old. These participants took the English Speaking-Listening as an obligatory course. To ensure the homogeneity of the participants, the PET language proficiency test was administered and those students who scored two standard deviations above and below the mean were selected. Therefore, 34 students comprised the participants of the study and they were randomly assigned into the control and experimental groups, each with 17 participants.

\subsection{Instruments and Materials}

\subsubsection{Language Proficiency Test}

The whole modules of Priliminary English Test (PET) were used to test the proficiency level of the students to homogenize them. PET was published by ESOL (2006). It consists of four sections, each section consisted of 25 percent of the total 100 score: reading (35 items), writing ( 8 items), listening comprehension ( 25 items), and speaking (4 phases). The time allocated to the first section, including reading and writing, was 90 minutes. The timing for the second section, listening comprehension, was 30 minutes and for the speaking section was 10 minutes for each pair and 12 minutes for each group of three testees. The PET test was administered during two sessions at the beginning of the term.

\subsubsection{Speaking Pretest}

The speaking section of Preliminary English Test (PET), consisted of four subparts, was employed as the pretest in this study. It started with a two-minute interaction of candidates with the interlocutor. In this phase, each interviewee had to respond to general questions about herself/himself on the topics such as jobs, family, sport, hobby, etc. Next, there was another two minute interaction during which the testees had to interact together on a visual stimulus. They had to use functional language to make suggestions and respond to them, to make 
recommendations, and to negotiate agreements. By the end of Phase Two, a card of a color photograph was given to each of the candidates in turn as a verbal prompt to talk about a particular topic up to a minute. During these three minutes, the participants were assessed on their photograph describing, managing discourse, and using appropriate vocabulary in a longer turn. All photographs used in this phase were related to the same topic. The last three minute discussion of speaking part of PET was a general conversation. The participants talked with each other in this phase on the topic established on the theme of last part. Their discussion was about their opinions, experiences, likes/dislikes, habits, preferences, etc. The final scores of testees were utilized to ensure the homogeneity of control and experimental groups, with regard to their speaking ability, before the beginning of the treatment.

Meanwhile, it should be note that two raters scored the speaking test. Based on the PET speaking scale, the subjects were scored by the interlocutor, who conducted the speaking test, from 0-5 on their global achievement. Meanwhile, they were scored by the assessor, who was present in the test room but not engaged the test orally, from $0-20(0-5=$ grammar and vocabulary, $0-5=$ discourse management, $0-5=$ pronunciation, and $0-5=$ interactive communication). The sum of the ratings for each individual was considered as her total score on the speaking test.

\subsubsection{Speaking Posttest}

During the seventh session of the study, the same speaking section of PET was used in the posttest when the four sessions of the treatment were ended. It should be noted that the first two sessions were used to test the subjects of the study.

\subsubsection{Classroom Materials}

Classroom materials included a story book entitled "Lord Arthur Savile's Crime and Other Stories", by Oxford University Press (ESOL, 2003) and students' news from different sources. Every student had to come to the class with a piece of interesting news from newspapers, internet, or any other source. Each one had to talk about his/her news for about 3-5 minutes every session.

\subsection{Procedure}

After the homogenous participants of the study were selected, one of the researchers, who was the teacher of the groups of this study, conducted the treatment sessions. During these sessions, the two groups underwent a teaching process by the teacher for one month (4 sessions, each with three hours length) in a way that the experimental group received a treatment, while the control group received a placebo. That meant in experimental group, but not in the control group, the teacher taught four categories of textual metadiscourse markers including additional connectives (e.g. "also", "besides", "furthermore", "in addition", "moreover", "what is more"); contrastive connectives (e.g. "but", "despite", "in spite of", "on the contrary", "conversely", "instead", "on the one/other hand", "similarly", "but then", "or rather"); sequencers (e.g. "firstly/secondly/thirdly/fourthly", "finally", "next", "(to) start with", "then", "after that", "in the end"); and summative connectives (e.g. "all in all", "in all", "briefly", "in brief", "in conclusion", "in general", "in short", "in summary", "summing up", "summarizing", "to sum up").

For instruction of such categories, the teacher introduced one category of metadiscourse markers to the class explicitly in each session. She then modeled the students how to use such markers. For example, regarding the category of sequencers, she explained how sequencers are used in a recipe by the following example of her own:

T: "In order to cook dinner, you must buy a good cookbook firstly."

After that, she asked the students to practice what presented to them by the repetition of her examples:

T: "In order to cook dinner, you must buy a good cookbook firstly."

S: "In order to cook dinner, you must buy a good cookbook firstly."

She then elicited some new sentences from the class:

T: "Now, who can make another sentence by firstly?"

S: "In order to study the book, we must open our books firstly."

Later as a controlled speaking practice, the teacher asked the students to think in pairs about how to narrate their pieces of previously assigned story, which they must have been studied at home. The students were allowed to use only the group of metadiscourse markers, which they had newly learned. Here are some examples of the students' sentences:

S1: Lord Arthur visited Mr Podgers in the party firstly. 
S2: He then asked him to look at his palm because he was a palmist.

Later, as a post speaking task activity, the teacher asked her students to talk about their own pieces of news. While the students of experimental group underwent such a process, the students in control group didn't receive any instruction regarding the metadiscourse markers. They were only asked to narrate the assigned story book in pairs and then talk about their news in the classroom.

During the last step, the researcher administered the same speaking section of the PET to the students as the speaking posttest.

\section{Results}

\subsection{Administering the PET}

The PET test consisted of four sections (reading, writing, listening, and speaking) was administered to 50 intermediate level university students. The descriptive statistics of this test are shown in Table 1. The students whose scores were within two standard deviations above and below the mean were selected for the study. In sum, 34 students were assigned to two experimental and control groups.

Table 1. Descriptive statistics of the PET

\begin{tabular}{lllll}
\hline $\mathrm{N}$ & Minimum & Maximum & Mean & Std. Deviation \\
\hline 50 & 15 & 98 & 59.38 & 26.029 \\
\hline
\end{tabular}

\subsection{Inter-Rater Reliability for the Scores of the Speaking Section of PET}

In this section of the PET, each subject was assessed by two raters, the interlocutor and the assessor, using the analytic scale of PET speaking test (2006). Table 2 shows an acceptable consistency between the two sets of scores on the speaking pretest.

Table 2. Inter-rater reliability of scoring the PET speaking section

\begin{tabular}{lllllll}
\hline Raters & $\mathrm{N}$ & Minimum & Maximum & Mean & Std. Deviation & Pearson Correlation \\
\hline Assessor & 50 & 10 & 23 & 16.88 & 3.555 & \multirow{2}{*}{0.751} \\
interlocutor & 50 & 2 & 5 & 3.52 & 0.735 & \\
\hline
\end{tabular}

\subsection{Checking the Homogeneity of the Two Groups}

During the next phase, the scores of the participants on the speaking section of PET in the pretest were analyzed separately to ensure the participants of the two groups were similar in terms of their speaking ability before the treatment. Table 3 shows the descriptive statistics of the speaking section.

Table 3. Descriptive statistics of the scores of both groups on the speaking pretest

\begin{tabular}{llllll}
\hline Groups & $\mathrm{N}$ & Minimum & Maximum & Mean & Std. Deviation \\
\hline Control & 17 & 12 & 23 & 18.00 & 3.500 \\
Experimental & 17 & 13 & 26 & 20.18 & 3.432 \\
\hline
\end{tabular}

In order to ensure the two groups were homogenous, the researchers carried out an independent samples t-test. Based on Table 4, it could be concluded that there was no significant difference between the groups in terms of their speaking ability before the instruction. As indicated in Table 4, the Levene sig. value was 0.811 , which was higher than 0.05 level of significance.This meant that the variances of the two groups could be assumed equal. Also, the Sig. (2-tailed) was .076 at 32 degrees of freedom. It was higher than 0.05 . 
Table 4. Independent samples t-test of the means of the two groups on the speaking pretest

\begin{tabular}{|c|c|c|c|c|c|c|c|c|c|c|}
\hline & & \multicolumn{9}{|c|}{$\begin{array}{l}\text { Levene's Test } \\
\text { for Equality t-test for Equality of Means } \\
\text { of Variances }\end{array}$} \\
\hline & & \multirow[t]{2}{*}{ F } & \multirow[t]{2}{*}{ Sig. } & \multirow[t]{2}{*}{$\mathrm{t}$} & \multirow[t]{2}{*}{ df } & \multirow[t]{2}{*}{$\begin{array}{l}\text { Sig. } \\
\text { (2-tailed) }\end{array}$} & \multirow[t]{2}{*}{$\begin{array}{l}\text { Mean } \\
\text { Difference }\end{array}$} & \multirow[t]{2}{*}{$\begin{array}{l}\text { Std. Error } \\
\text { Difference }\end{array}$} & \multicolumn{2}{|c|}{$\begin{array}{l}95 \% \text { Confidence } \\
\text { Interval of the } \\
\text { Difference }\end{array}$} \\
\hline & & & & & & & & & Lower & Upper \\
\hline $\begin{array}{l}\text { Speaking } \\
\text { Pretest }\end{array}$ & $\begin{array}{l}\text { Equal } \\
\text { variances } \\
\text { assumed }\end{array}$ & .058 & .811 & -1.831 & 32 & .076 & -2.176 & 1.189 & -4.598 & .245 \\
\hline
\end{tabular}

\subsection{Speaking Posttest}

Following the 4-session instruction, the speaking posttest was administered to both groups. Table 5 presents the descriptive statistics of the speaking posttest of the two groups.

Table 5. Descriptive statistics of the scores of both groups on the speaking posttest

\begin{tabular}{llllll}
\hline Groups & $\mathrm{N}$ & Minimum & Maximum & Mean & Std. Deviation \\
\hline Control & 17 & 6 & 27 & 20.06 & 5.202 \\
Experimental & 17 & 16 & 30 & 24.24 & 3.562 \\
\hline
\end{tabular}

\subsubsection{Inter-Rater Reliability of Scoring the Speaking Posttest}

Since each subject was assessed by two raters, the interlocutor and the assessor, the inter-rater reliability was calculated after the speaking posttest. The result $(r=0.870)$ proved a relatively high agreement between the two scorings (Table 6).

Table 6. Inter-rater reliability of scoring the speaking posttest

\begin{tabular}{lllllll}
\hline Raters & $\mathrm{N}$ & Minimum & Maximum & Mean & Std. Deviation & Pearson Correlation \\
\hline Assessor & 34 & 5 & 25 & 18.29 & 4.079 & \multirow{2}{*}{0.870} \\
Interlocutor & 34 & 1 & 5 & 3.85 & 0.892 & \\
\hline
\end{tabular}

\subsubsection{Results of Data Analysis for the First Research Question}

To answer the first research question, the scores of the two groups on the speaking posttest were used for the analysis. As indicated in Table 7, the Levene sig. value was 0.545, which exceeded 0.05 level of significance. This meant that the variances of the two groups could be assumed equal. The sig. (2-tailed) value was 0.01 at 32 degrees of freedom. It was lower than 0.05 significance level. Thus, there is a significant difference between the groups.

Table 7. Independent samples t-test of the means of the two groups on the speaking posttest

\begin{tabular}{|c|c|c|c|c|c|c|c|c|c|}
\hline & \multicolumn{8}{|c|}{$\begin{array}{l}\text { Levene's Test } \\
\text { for Equality t-test for Equality of Means } \\
\text { of Variances }\end{array}$} \\
\hline & & \multirow[t]{2}{*}{$\mathrm{F}$} & \multirow[t]{2}{*}{ Sig. } & \multirow[t]{2}{*}{$\mathrm{t}$} & \multirow[t]{2}{*}{$\mathrm{df}$} & \multirow[t]{2}{*}{$\begin{array}{l}\text { Sig. } \\
\text { (2-tailed) }\end{array}$} & \multirow[t]{2}{*}{$\begin{array}{l}\text { Mean } \\
\text { Difference }\end{array}$} & \multirow[t]{2}{*}{$\begin{array}{l}\text { Std. Error } \\
\text { Difference }\end{array}$} & $\begin{array}{l}95 \% \text { Confidence } \\
\text { Interval of the } \\
\text { Difference }\end{array}$ \\
\hline & & & & & & & & & Lower Upper \\
\hline $\begin{array}{l}\text { Speaking } \\
\text { Posttest }\end{array}$ & $\begin{array}{l}\text { Equal } \\
\text { variances } \\
\text { assumed }\end{array}$ & .375 & .545 & -2.731 & 32 & .010 & -4.176 & 1.529 & $-7.291 \quad-1.062$ \\
\hline
\end{tabular}




\subsubsection{Results of Data Analysis for the Second Research Question}

To answer the second research question, the scores of the experimental group on the speaking pretest and posttest were used for the analysis. As indicated in Table 8, the sig. (2-tailed) was lower than 0.05 level of significance. So, a significant difference was proved between the pretest and posttest in the experimental group.

Table 8. Paired samples t-test of the means of the experimental group on the speaking pretest and posttest

\begin{tabular}{|c|c|c|c|c|c|c|c|c|c|}
\hline & & \multicolumn{5}{|c|}{ Paired Differences } & \multirow{3}{*}{$\mathrm{t}$} & \multirow{3}{*}{$\mathrm{df}$} & \multirow{3}{*}{$\begin{array}{l}\text { Sig. } \\
\text { (2-tailed) }\end{array}$} \\
\hline & & \multirow[t]{2}{*}{ Mean } & \multirow{2}{*}{$\begin{array}{l}\text { Std. } \\
\text { Deviation }\end{array}$} & \multirow{2}{*}{$\begin{array}{l}\text { Std. } \\
\text { Error } \\
\text { Mean }\end{array}$} & \multicolumn{2}{|c|}{$\begin{array}{l}95 \% \text { Confidence Interval } \\
\text { of the Difference }\end{array}$} & & & \\
\hline & & & & & Lower & Upper & & & \\
\hline $\begin{array}{l}\text { Pair1 } \\
\text { Experimental } \\
\text { Group }\end{array}$ & $\begin{array}{l}\text { Speaking } \\
\text { Pretest } \\
\text { speaking } \\
\text { Posttest }\end{array}$ & -4.059 & 2.727 & .661 & -5.461 & -2.657 & -6.138 & 16 & .000 \\
\hline
\end{tabular}

\subsubsection{Results of Data Analysis for the Third Research Question}

To answer the last research question, the scores of the control group on the speaking pretest and posttest were used for the analysis. As indicated in Table 9, the sig. (2-tailed) was .068. It exceeded 0.05 level of significance. Therefore, no significant difference was proved between the pretest and posttest in the control group.

Table 9. Paired samples t-test of the means of the control group on the speaking pretest and posttest

\begin{tabular}{|c|c|c|c|c|c|c|c|c|c|}
\hline & & \multicolumn{5}{|c|}{ Paired Differences } & \multirow{3}{*}{$\mathrm{t}$} & \multirow{3}{*}{$\mathrm{df}$} & \multirow{3}{*}{$\begin{array}{l}\text { Sig. } \\
\text { (2-tailed) }\end{array}$} \\
\hline & & \multirow[t]{2}{*}{ Mean } & \multirow{2}{*}{$\begin{array}{l}\text { Std. } \\
\text { Deviation }\end{array}$} & \multirow{2}{*}{$\begin{array}{l}\text { Std. } \\
\text { Error } \\
\text { Mean }\end{array}$} & \multicolumn{2}{|c|}{$\begin{array}{l}95 \% \text { Confidence Interval } \\
\text { of the Difference }\end{array}$} & & & \\
\hline & & & & & Lower & Upper & & & \\
\hline $\begin{array}{l}\text { Pair1 } \\
\text { Control } \\
\text { Group }\end{array}$ & $\begin{array}{l}\text { Speaking } \\
\text { Pretest } \\
\text { speaking } \\
\text { Posttest }\end{array}$ & -2.059 & 4.337 & 1.052 & -4.289 & .171 & -1.957 & 16 & .068 \\
\hline
\end{tabular}

\section{Discussion}

In this study, the effect of metadiscourse instruction on speaking ability was studied. The results showed that the speaking ability was significantly improved in the experimental group after the treatment. While the speaking scores of the control group remained almost the same. This could lead to more emphasis on the role of learning Metadiscourse markers in enhancing the speaking ability. This is in accordance with the study of Pérez and Macia (2002), who suggested that metadiscourse markers enrich the speech, since textual discourse helps to structure discourse and hence they act as an aid for foreign language learners.

Moreover, although it cannot be emphasized widely, metadiscourse instruction can be a valuable cause to extend turns in pair discussions. It is a strategy to save the time to think for the next sentences for students with lower fluency. As a result, not only is it beneficial to remind the students to take care of their hesitations with such an easy strategy in speaking tests, but the characteristics of metadiscourse words, as fillers, make them good tools for assessors to check the speaker's skill. However, successful integration of the metadiscourse instruction into EFL classrooms is dependent on teacher's method. Therefore, teachers can benefit from metadiscourse instruction to enhance the speaking ability of their students. Furthermore, learner's needs, attitudes, and proficiency levels must be considered (Aminzadeh \& Entezari, 2011). It should be noted finally that further research is needed to reveal the relationship between the learner styles and variables and frequency of metadiscourse instruction. 


\section{References}

Aminzadeh, R., \& Entezari Maleki, S. (2011). Impact of reduction recasts on improvement of EFL learners' speaking ability. In B. Boufoy-Bastick (Ed.), The international handbook of cultures of teacher education: Comparative international issues in curriculum and pedagogy (pp. 225-243). Strasbourg, France: Analytrics.

Amiryousefi, M., \& Eslami Rasekh, A. (2010). Metadiscourse: Definitions, issues and its implications for English teachers. English Language Teaching, 3(4), 159-167. http://dx.doi.org/10.5539/elt.v3n4p159

Bruce, N. J. (1989). The role of metadiscourse, speech acts and the language of abstraction in a top-down approach to teaching English for academic purposes. Paper presented at the European Language for Special Purposes symposium, $7^{\text {th }}$ Budapest Hungary. University of Technology (ERIC Document Reproduction Service No. ED331299).

Burns, A., \& Joyce, H. (1997). Focus on speaking. Sydney: National Center for English Language Teaching and Research.

Camiciottoli, B. C. (2003). Metadiscourse and ESP reading comprehension: An exploratory study. Reading in a Foreign Language, 15(1), 1-16. Retrieved from http://nflrc.hawaii.edu/rfl/April2003/camiciottoli/ camiciottoli.html

Hyland, K. (1998). Persuasion and context: The pragmatics of academic metadiscourse. Journal of Pragmatics, 30, 437-455. http://dx.doi.org/10.1016/S0378-2166(98)00009-5

Hyland, K. (2005). Metadiscourse: Exploring interaction in writing. London: Continuum.

Kong, R., \& Xin, X. (2009). Empirical study on metadiscourse in Chinese EFL learners' oral communication. CELEA Journal, 32(1), 52-64.

Nash, W. (1992). An uncommon tongue: The uses and resources of English. New York: Taylor \& Francis.

Pérez, M. A., \& Macià, E. A. (2002). Metadiscourse in lecture comprehension: Does it really help foreign language learners? Atlantis Journal, 24(1), 3-21.

Schiffrin, D. (1980). Metatalk: Organisational and evaluative brackets in discourse. Sociological inquiry. Language and Social Interaction, 50, 199-236.

Swales, J. M. (1990). Genre analysis: English for specific purpose in academic and research setting. New York: Cambridge University Press.

Kopple, W. J. V. (1997). Refining and applying views of metadiscourse. Phoenix, AZ. http://dx.doi.org/ED411529

Webb, N. (1982). Student interaction and learning in small groups. Review of Educational Research, 5, 421-445.

\section{Copyrights}

Copyright for this article is retained by the author(s), with first publication rights granted to the journal.

This is an open-access article distributed under the terms and conditions of the Creative Commons Attribution license (http://creativecommons.org/licenses/by/3.0/). 